\title{
Ultra-wide field imaging of bilateral idiopathic retinal dialysis
}

\author{
Vinod Kumar, Raghav Dinesh Ravani, Nikhil Kuthirummal, Kabiruddin Molla
}

Dr Rajendra Prasad Centre for Ophthalmic Sciences, All India Institute of Medical Sciences, New Delhi, India

\section{Correspondence to} Dr Vinod Kumar, drvinod_agg@yahoo.com

Accepted 16 June 2016

\section{CrossMark}

To cite: Kumar $\mathrm{V}$,

Ravani RD, Kuthirummal N, et al. BMJ Case Rep Published online: [please include Day Month Year] doi:10.1136/bcr-2016216212

\section{DESCRIPTION}

A healthy 22-year-old man presented with decreased vision OD for 1 month. There was no history of trauma. Best-corrected visual acuity (BCVA) was 20/400 OD and 20/20 OS. Anterior segment $\mathrm{OU}$ was normal. Dilated fundus examination OD (figure 1A) showed large inferotemporal retinal dialysis (black arrows), an intraretinal macrocyst at its edge (blue arrowheads) and rhegmatogenous retinal detachment (RRD) reaching up to the fovea. Yellowish-white vitreous opacities were noted in the inferior fundus (blue arrows). Fundus OS (figure 1B) showed a large inferotemporal dialysis with microcystoid changes at its edge. The patient was diagnosed with bilateral idiopathic retinal dialysis, and underwent scleral buckling in $\mathrm{OD}$ and laser photocoagulation in OS. BCVA OD at 1 month was $20 / 80$ with attached retina. The clinical picture remained stable at 3 months follow-up.

Idiopathic retinal dialysis is characteristically bilateral, involves the inferotemporal quadrant and leads to slowly progressive RRD. ${ }^{1}$ These images highlight the importance of screening inferotemporal periphery of fellow eyes of all patients with RRD due to inferotemporal dialysis.

Ultra-wide field (UWF) imaging using an Optos T×200 (Optos PLC, Dunfermline, Scotland, UK) can be useful for retinal periphery examination and documentation. The apparatus images up to $200^{\circ}$ of the retina and provides quick, high-resolution images of the retina, without requiring extensive patient cooperation. UWF imaging has been found useful in patients with retinal detachment. ${ }^{2}$ In the current case, UWF imaging was able to document the peripheral features of the retina, for which one has to rely on coloured fundus drawings. It also helps clinicians when counselling patients.

\section{Learning points}

- Inferotemporal retinal dialysis, unlike superonasal dialysis, is not always related to trauma.

- Fellow eyes of those with inferotemporal retinal dialysis must be screened for retinal dialysis in the inferotemporal quadrant.

- Ultra-wide field imaging is a useful tool for examination and documentation of peripheral retinal pathology like retinal dialysis.

\section{Competing interests None declared.}

Patient consent Obtained.

Provenance and peer review Not commissioned; externally pee reviewed.

\section{REFERENCES}

1 Kinyoun JL, Knobloch WH. Idiopathic retinal dialysis. Retina 1984;4:9-14

2 Witmer MT, Cho M, Favarone G, et al. Ultra-wide-field autofluorescence imaging in non-traumatic rhegmatogenous retinal detachment. Eye (Lond) 2012;26:1209-16.
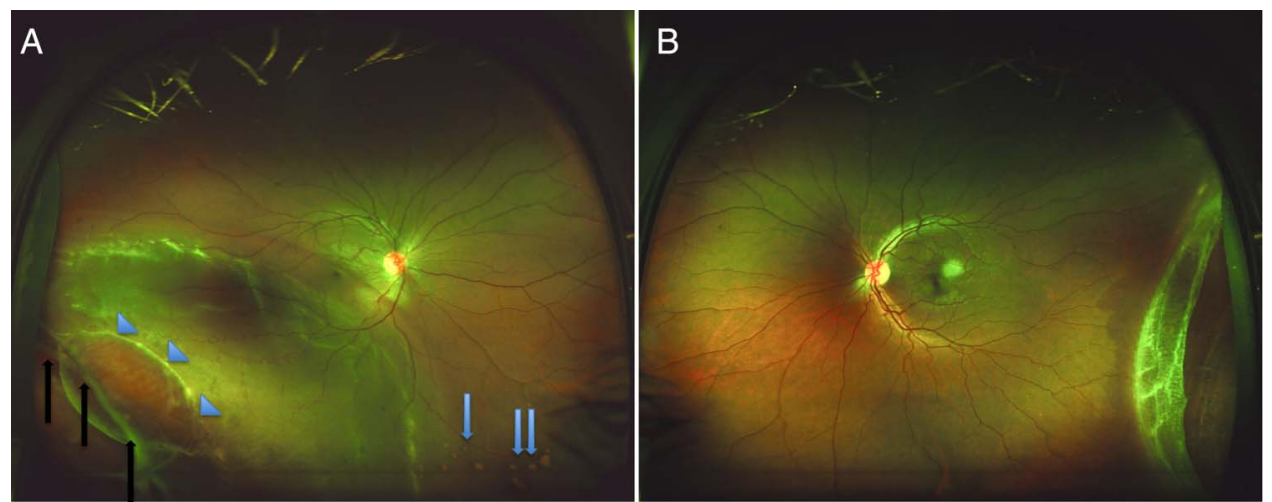

Figure 1 Ultra-wide field pseudocolour photographs of the right (1A) and left (1B) eyes, showing bilateral idiopathic retinal dialysis with retinal detachment in the right eye. Black arrows, blue arrowheads and blue arrows in figure $1 \mathrm{~A}$ show retinal dialysis, intraretinal macrocyst and vitreous opacities, respectively. 


\section{Images in...}

Copyright 2016 BMJ Publishing Group. All rights reserved. For permission to reuse any of this content visit http://group.bmj.com/group/rights-licensing/permissions.

BMJ Case Report Fellows may re-use this article for personal use and teaching without any further permission.

Become a Fellow of BMJ Case Reports today and you can:

- Submit as many cases as you like

- Enjoy fast sympathetic peer review and rapid publication of accepted articles

- Access all the published articles

- Re-use any of the published material for personal use and teaching without further permission

For information on Institutional Fellowships contact consortiasales@bmjgroup.com

Visit casereports.bmj.com for more articles like this and to become a Fellow 